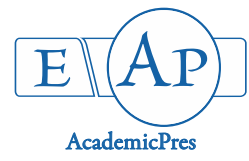

\title{
Yellow Rust (Puccinia striiformis): a Serious Threat to Wheat Production Worldwide
}

\author{
Siham KHANFRI, Mohammed BOULIF, Rachid LAHLALI* \\ Ecole Nationale d'Agriculture de Meknès, Phytopathology Unit, Department of Plant Protection and Environment, Km10, Rte Haj Kaddour, \\ BP S/40, Meknès 50001, Morocco; rlablali@enameknes.ac.ma (*orresponding author)
}

\begin{abstract}
Wheat (Triticum sp. L.), as one of the first domesticated food crops, is the basic staple food for a large segment of population around the world. The crop though is susceptible to many fungal pathogens. Stripe rust is an important airborne disease caused by Puccinia striiformis $(P s t)$ and is widespread wherever wheat is cultivated throughout the world, in temperatecool and wet environments. The causal fungus of stripe rust or yellow rust is an obligate parasite that requires another living host to complete its life cycle. Pst includes five types of spores in the life cycle on two distinct hosts. Stripe rust is distinguished from other rusts by the dusty yellow lesions that grow systemically in the form of streaks between veins and on leaf sheaths. The importance and occurrence of stripe rust disease varies in cultivated wheat, depending on environmental conditions (moisture, temperature, and wind), inoculum levels and susceptible host varieties. Transcaucasia was previously thought to be the center of origin for the pathogen. However, new findings further underlined Himalayan and near-Himalayan regions as center of diversity and a more tenable center of origin for $P$. striiformis. Long-distance dispersal of stripe rust pathogen in the air and occasionally by human activities enables $P s t$ to spread to new geographical areas. This disease affects quality and yield of wheat crop. Early seeding, foliar fungicide application and cultivation of resistant varieties are the main strategies for its control. The emergence of new races of $P s t$ with high epidemic potential which can adapt to warmer temperatures has expanded virulence profiles. Subsequently, races are more aggressive than those previously characterized. These findings emphasize the need for more breeding efforts of resistant varieties and reinforcement of other management practices to prevent and overcome stripe rust epidemic around the world.
\end{abstract}

Keywords: epidemiology; management; Puccinia striiformis; stripe rust; wheat

\section{Introduction}

Wheat represents approximately $19 \%$ of global major cereal crop production. East African countries, North Africa and Middle East consume over $150 \%$ of their own wheat production and are heavily dependent on imports to meet their food security (FAOSTAT, 2018). Demand for wheat in the world continues to grow rapidly with increasing population growth. It is predicted that the world population will surpass 8 billion by 2025 and the demand is expected to increase to 760 million tons by 2020 and exceed 880 million metric tons by 2050 (Dixon et al., 2009), thus the production needs to increase at least by $50 \%$ by the year 2025 (Yadav et al., 2017).

Crop production throughout the world is reduced significantly by biotic and abiotic stresses. Diseases reduce approximately $14 \%$ of world crop production. Wheat is susceptible to many pathogens including stem rust caused by Puccinia graminis f.sp. tritici, leaf or brown rust caused by $P$. triticina and stripe or yellow rust caused by $P$. striiformis f.sp. tritici $(P s t)$; they are the most important diseases of wheat which cause important losses of yield (Ellis et al., 2014). Among rust diseases affecting wheat, stripe rust was considered to be the most the most destructive (Chen, 2005; Hovmoller et al., 2011). This disease can cause significant reductions in yield and result in total losses of the production (Ali et al., 2017). The use of resistant cultivars, chemical substances and early seedling are the main methods for the control of this disease.

Stripe rust causes many challenges to farmers around the world because the majority of winter wheat cultivars are either susceptible or possess low level of resistance to this disease (Sharma et al., 2016). Until now, stripe rust on susceptible wheat cultivars is mainly controlled by fungicide 
applications. Different fungicides were used to control the stripe rust significantly, but their efficacy was shown to differ according to their applied concentrations (Conner et al., 1988). Furthermore, the most significant problem encountered in the control of this disease by farmers was the optimum periods of fungicidal applications because any lack of these chemical treatments might lead to the important losses of yield. Among fungicides used to control stripe rust, researchers assayed different active ingredients at different concentrations rate such as epoxiconazole, pyraclostrobin, and propiconazole and found their efficacies are highly correlated with their applied concentrations (Sharma et al., 2016). In most reported cases, preventive treatments were more efficient (Boshoff et al., 2003). Although chemical treatments are efficient in avoiding a stripe rust epidemic and contributed efficiently in preserving yield, their use is still criticized and not suitable due to their higher cost and their adverse effects on both environment and human health. To date, thousands of studies were conducted on the epidemiology and control of stripe rust. The present overview aimed at providing a basic understanding of the epidemiology and control of wheat yellow rust. Therefore, this review emphasizes the following areas: wheat stripe rust biology and development; migration and introduction of the pathogen; economic importance; stripe rust management; and current state and challenges.

Wheat (Triticum spp.) taxonomy and biology

Wheat is one of the important crops worldwide that ranks third behind corn and rice (Asseng et al., 2011). It was cultivated for over 8,000 years (Curtis, 2002) providing the basic nutritive elements (carbohydrates, proteins, vitamins, minerals and fiber) to humans. More than 4.5 billion people in 94 developing countries depend on food products made from wheat in addition to rice and maize (Shiferaw et al., 2011).
Wheat is a $\mathrm{C}_{3}$ plant that is well suitable to cool environment and adapted to a broad range of climates: from wet temperate to dry and high rainfall areas, and from warm- humid to dry- cold environment (Acevedo et al., 2006). The optimum growing temperature for wheat lies between $18^{\circ} \mathrm{C}$ and $24^{\circ} \mathrm{C}$ and the minimum and maximum growth temperatures range from $3{ }^{\circ} \mathrm{C}$ to $4^{\circ} \mathrm{C}$ and from 30 ${ }^{\circ} \mathrm{C}$ to $32^{\circ} \mathrm{C}$ respectively (Getie, 2015). In addition, wheat is of two types based on the sowing season: spring wheat and winter wheat. Unlike spring wheat, which has a short period of vernalisation, winter wheat requires a long period of cold temperatures for flowering (Curtis et al., 2002).

Some researchers classify wheat within the genus of Triticum that is a part of the Poaceae family. According to the number of chromosomes pairs, wheat is further subdivided into many species. Furthermore, an accurate taxonomical classification for wheat species is necessary for the breeding purposes and conservation of wheat biodiversity. Goncharov's classification has 29 species; six of them are synthetic species (Fig. 1) (Goncharov et al., 2009).

\section{Wheat production in the world and in Morocco}

Wheat is the largest grown crop in the world with a $22 \%$ of the total arable land in the world (Leff et al., 2004). In $2015 / 2016$, wheat world production reached $734 \mathrm{Mt}$ and it is estimated to reach $757 \mathrm{Mt}$ during the growing season 2017-2018 (FAO, 2018). The European Union is the largest producer of the wheat (Siad et al., 2017) with 155 million tons in 2014, followed respectively by China (126 million tons), India (95 million tons), Russia (59 million tons), United States ( 55 million tons), Canada (29 million tons), Australia (26 million tons), Ukraine (24 million tons) and Argentina (12 million tons). The major exporters of wheat are the United States, Canada, Australia, the European Union, Russia, Ukraine and Argentina (USDA, 2014).

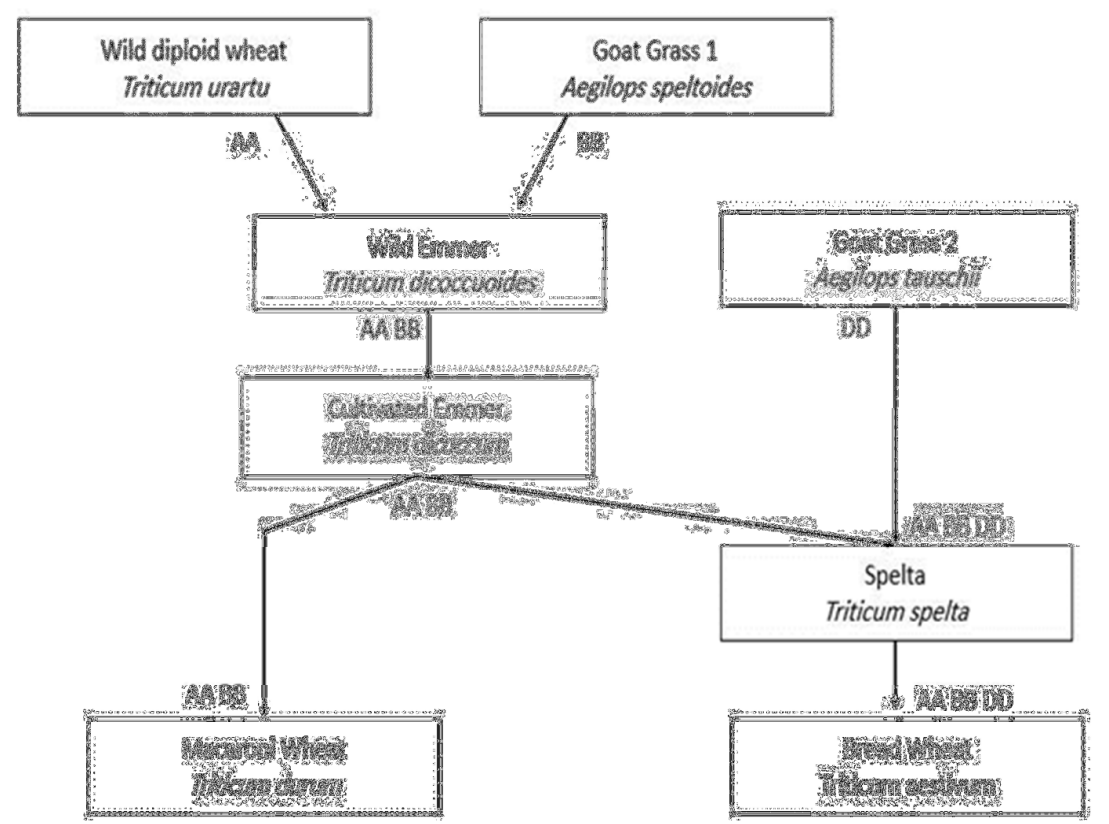

Fig. 1. Evolution of domesticated wheat (Peng et al., 2011) 
412

Morocco presents suboptimal agro-meteorological conditions for wheat growing (Mrabet, 2000). The wheat growing regions can be classified into 6 agro-ecological regions (Gommes et al., 2009), ranging from a typical Mediterranean climate in the Northern coasts to continental conditions in the Central regions and in the mountainside areas in the West High Atlas, and to semiarid environments in the Southern part of the wheatcropped area at the North of the Sahara (Confalonieri et al., 2013). Soft wheat production is concentrated in the Atlantic plains of Morocco, from semi-arid to sub humid provinces, whereas durum wheat is mainly grown in the semi-arid southwestern plains (Balaghi et al., 2012).

A total of 7.1 million tons of wheat was harvested in 2017 in Morocco, which represents an increase of 33\% above the average yield of the five previous years (FAO, 2017). The cereals sector is a fundamental sector of agricultural production in Morocco. Cereal production contributes about $15-20 \%$ of the Moroccan gross agricultural product. It plays an outstanding role in terms of the annual grain-sown areas of arable land, rural employment and the utilization of processing industry (El Mekki, 2006).

In Morocco, wheat is the most consumed cereal; its consumption for 2016-2017 was estimated at 10.2 MMT. Morocco's High Commission for planning (HCP) estimated wheat consumption at $216 \mathrm{~kg}$ per capita annually (USDA, 2017). Morocco is one of the world's major importers of wheat. Its imports requirements of common and durum wheat are forecasted to reach 4.5 million tons in 2017-2018. EU and Black Sea countries are the top exporters of the common wheat to Morocco, while Canada is the top supplier of durum wheat (FAO, 2017). According to FAS/Rabat, Morocco forecasted the harvested area of wheat for 2017 at 3.3 million hectares (USDA, 2017).

\section{Wheat stripe rust disease}

The causal agent of stripe rust, also known as yellow rust, belongs to the order of Pucciniales of the Basidiomycota. It is an obligate parasite that requires another living host to complete its life cycle. Puccinia striiformis Westend. f.sp. tritici is the fungal pathogen responsible for the disease and it was coined by Hylander et al. (1953) and later reviewed by Cummins and Stevenson (Line, 2002). This nomenclature had undergone several changes and was given various names such as Uredo glumarum (Schmidt, 1827), Puccinia striaeformis (Westendorp, 1854), Puccinia straminis (Fuckel 1860), Puccinia glumarum (Eriksson and Henning 1894) (Chen, 2005).

\section{The life cycle of Puccinia striiformis}

Like many rust fungi, $P$. triiformis $(P s t)$ alternates between hosts during its life cycle (Fig. 2) and has separate hosts for asexual and sexual phases (Berlin et al., 2017). Pst includes five types of spores in the life cycle (Schwessinger, 2017) on two taxonomically unrelated hosts; it alternates between a graminaceous host for asexual reproduction and barberry where sexual reproduction may occur (Jin et al., 2010). Urediniospores and teliospores of the fungus are dikaryotic, whereas teliospores produce haploid basidiospores (Chen, 2005).

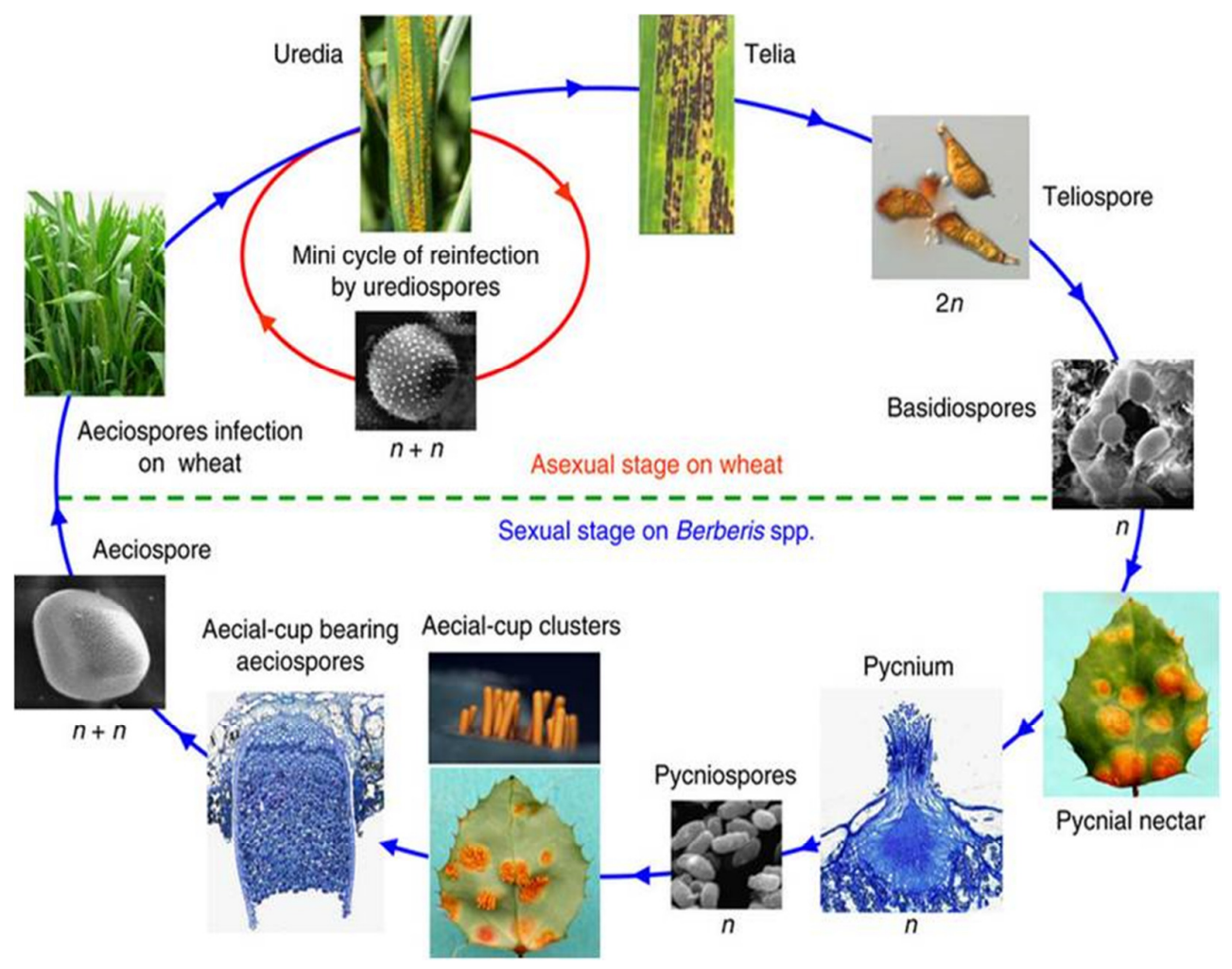

Fig. 2. The life cycle of Puccinia striformis f.sp. tritici (Zheng et al., 2013) 
Pycnial and aecial spore stages of the fungus were recently confirmed (Jin et al., 2010). The diakaryotic phase of the life cycle is confined to the primary host (wheat), upon which urediniospores, teliospores and basidiospores are produced. As the nutrient supply from the infected tissues declines, the telia stage is initiated. Teliospores overwinter on residual senesced tissues and germinate the following spring to produce four haploid basidiospores that infect the alternate host (Berberis spp.) ( Sørensen, 2012; Baily, 2013) upon which pycniospores and aeciospores are produced on the upper and lower leaf surface, respectively (Jin et al., 2010).

\section{Infection process and infection structure}

Because of some limitations of the staining and microscopy techniques, an accurate description of how stripe rust fungus infects its hosts was not given until 1981 by Cartwright and Russell. They used fluorescence microscopy to observe the fungal structures in the whole leaves of both seedlings and adult plants. Their findings showed that urediniospores of $P$. striiformis infect wheat by entering the leaf through stomata. Spores germinate and form a germinative tube that grows and moves along the leaf to enter through the opening stomata (Cartwright et al., 1981; Sørensen, 2012).

Unlike other rust fungi, $P$. striiformis does not differentiate an appressorium (Moldenhauer et al., 2006). The germinative tube entrance initiates the formation of primary infection hyphae in the stomatal cavity and a contact of primary infection hyphae with mesophyll or on epidermal cell induce the formation of a haustrial mother cell $(\mathrm{hmc})$. A haustorium is established between the cell wall and the plasma membrane of the host cell (Ma et al., 2009; Sørensen, 2012). The secondary infection takes place, in which hyphae start developing from the primary infection hyphae and leads to the formation of an extensive hyphal network in the mesophyll layer. Approximately one week after the infection, the host response may appear, resulting in visible chlorotic spots appeared at the leaf surface. One week after, sporulation starts and the distinctive yellow spores will appear on leaf (Chen, 2005; Sørensen, 2012).

The optimum temperature for germination of the spores is $10-12{ }^{\circ} \mathrm{C}$. High temperature inhibits sporulation or force the fungus to enter dormancy. Under optimum

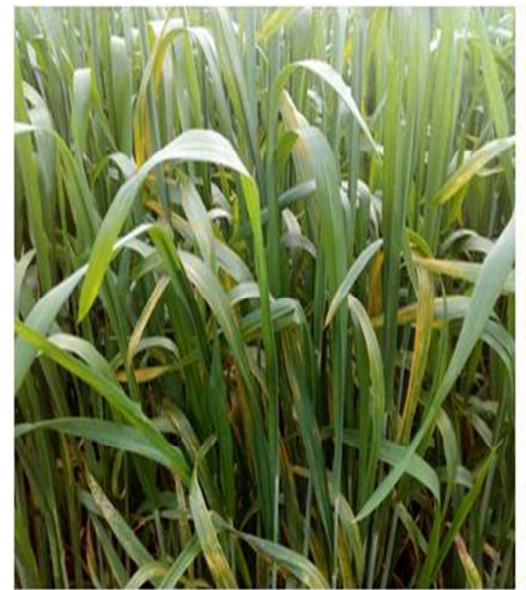

conditions, the time between inoculation and sporulation is 12-13 days (Line, 2002).

\section{Host range}

Wheat and barley are the major hosts of $P$. striiformis. The host range of stripe rust fungus includes 320 grass species, which are from up to 50 genera belonging to subfamilies of Festucoideae and Eragosteae. Aegilops, Agropyron, Bromus, Elymus, Hordeum and Triticum are the main genera that are affected by stripe rust (Brar, 2015).

Puccinia striiformis has been categorized into formae speciales based on specialization on different genera and species of host plants (Chen, 2005). Until now, six formae speciales were reported; five were named by Eriksson (1894) and more recently, Wellings et al. (2004) added a new forma specialis on Hordeum spp. discovered in Australia (Line, 2002). The relationship between P. striiformis f.sp. tritici and P. striiformis f.sp. hordei is not clear because they overlap their host range by infecting barley and wheat, respectively (Chen, 2005). For such anomalies, Gassner and Staib (1932) preferred to remain with race description and avoid the use of formae speciales (Chen, 2005).

\section{Disease symptoms on wheat and alternate hosts}

All growth stages of the plant are susceptible to infection (Line, 2002). Initial symptoms of stripe rust appear about one week after infection as small, yellow spots or flecks on the leaf sheaths. These spots develop into long and narrow stripes on leaf sheaths, glumes and awns (Fig. 3). Mature pustule will break open and release yellow-orange masses of urediniospores. The infected tissues may become brown and dry when plants begin to senesce or become stressed. The pathogen reduces plant vigor because it removes plant nutrients and water, and result in desiccation of leaves. Severe early infection can result in plant stunning (Line, 2002; Chen, 2005; Singh et al., 2017).

The basidiospores, produced by germinating teliospores, infect barberry (Berberis spp.) leaves and produce pycnia on the upper surface and acia on the lower surface (Fig. 4). Symptoms appear also on Oregon grape (Mahonia aquifolium), another alternate host of Pst. Similarly, pycnia and aecia are produced on the upper and lower side of leaves respectively (Wang et al., 2013).

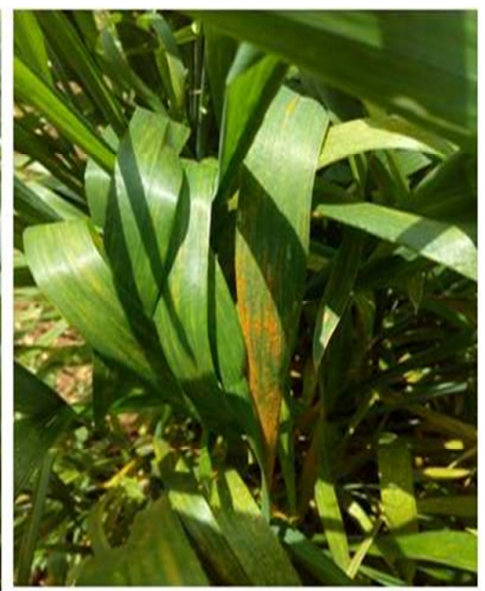

Fig. 3. Stripe rust symptoms observed on soft wheat cultivar 'Arrehane' during the growing season 2017-2018 at the experimental field (ENAM, Meknes, Morocco) 


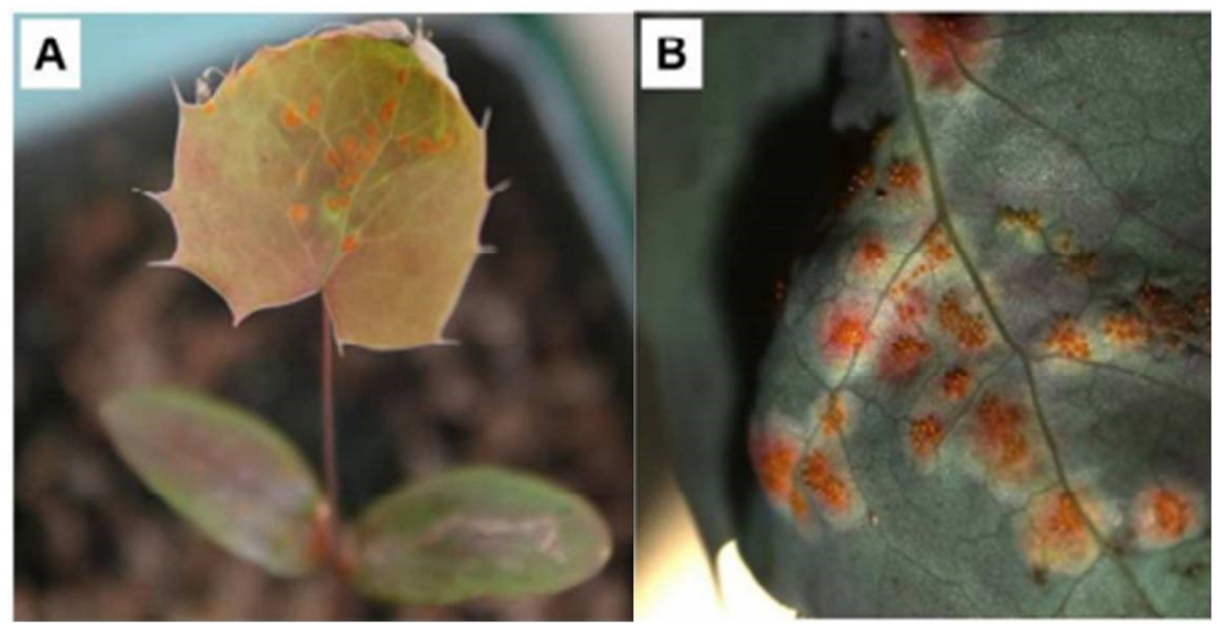

Fig. 4. Disease symptoms on Oregon grape (Mahonia aquifolium): pycnia (A) and aecia (B) produced on the upper and lower side of leaves respectively (Wang et al., 2013)

\section{Races pathogens on wheat}

There are two levels of specialization of P. striiformis; specialization between different genera and specialization in a single host at the genotype level. The second level of specialization, which divides Pst into races, is based on avirulence or virulence level to cultivar or genotype of wheat lines. Allison and Isenbeck (1930) were the first to define race concept based on the qualitative rust infection types. However, the host specificity of wheat genotypes was first recognized by Hungerford and Owens (1923) (Hovmoller et al., 2011).

\section{Pathogen virulence}

There are two distinct types of pathogenic races: those that interact with host varieties, and those that do not (Van der Plank, 1969). The gene for gene relationship is based on specific interactions between the genotype of the host and the genotype of pathogen. Van der Plank termed this type of interaction by vertical resistance. When differential interaction is absent, we talk about horizontal resistance (Brar, 2015).

The release of new more durable resistant cultivars is usually based on a better understanding of virulence variation and host-rust interaction (Webb et al., 2006). The mechanisms by which new races have appeared in Pst are unclear. High reproduction, capability of long distance dissemination and adaptation to various host species and environments, make Pst a highly variable pathogen (Wan et al., 2017).

Molecular characterization using various markers has generated numerous datasets to gain more understanding of mechanisms of variation in the pathogen population and determination of pathogen reproduction. It was conducted to collect information, which was otherwise impossible to generate through virulence characterization. Sequencing technologies had circumvented many limitations and had provided a rich source to study virulence variation and evolution of the stripe rust pathogen (Liu et al., 2012; Zheng et al., 2013).

The pathogen produces new races and genotypes through different mechanisms. Mutation was considered as the most important mechanism in generating new virulent races (Waqar et al., 2018). The pathogen can also produce new races through somatic recombination, sexual recombination and natural reproduction. Recent results suggest that genetic recombination contributes greatly to genomic diversification of Pst. Subsequently, high levels of genetic variation were observed in Pst populations from Western China and central Asia, where susceptible Berberis species are widely distributed (Zheng et al., 2013). This mechanism is still unclear (Waqar et al., 2018).

\section{Disease development}

When pathogen inoculum and susceptible host are present, the development of wheat stripe rust disease depends even more on weather conditions such as moisture, temperature and wind (Chen, 2005).

Spore germination, infection and survival of Pst, are directly affected by moisture. A continuous period of three hours of moisture is required for urediniospores germination and infection. A relative humidity near to saturation before inoculation increases rates of spore germination considerably (Line, 2002). Precipitation, especially light rains provide conducive conditions for infection. However, high moisture can also negatively affect spore viability. Spores kept in high moisture conditions lose their viability more quickly than those kept under dry conditions, because they lack the ability to induce fungistasis. Spores dispersal is also affected by moisture. Individual or cluster dispersal of urediniospores depends on the level of relative humidity. Cluster dispersal is limited on high humidity (Chen, 2005).

Temperature also influences the germination, infection and survival of spores. Spores are capable of germinating between $2.8-21.7^{\circ} \mathrm{C}$. However, they germinate most easily at $10-12{ }^{\circ} \mathrm{C}$ (Line, 2002). Sporulation can occur at $5-20^{\circ} \mathrm{C}$. Latent period, the time elapsing between infection process and sporulation, is estimated to be about $10-15$ days at 12 $19{ }^{\circ} \mathrm{C}$. The latent period of stripe rust can last up to 180 days at temperatures near to freezing (Sørensen, 2012). Lower temperatures adversely affect winter survival of the pathogen. Pathogen development could be stopped in 
temperatures below $-10{ }^{\circ} \mathrm{C}$ (Chen, 2005). High temperatures above $30{ }^{\circ} \mathrm{C}$ limit pathogen development and survival. Infections are more likely to occur at night, where both dew formation and cool temperatures occur together (Sørensen, 2012).

Wind inhibits spore germination by decreasing the moisture content of inoculum. Therefore, the infection rate is reduced, while the viability of the inoculum is increased. Wind also facilitates the spread of the inoculum over new territories and controls the time, rate and extent of infection. Long distance dispersion of stripe rust by the air resulted in its reintroduction and widespread (Chen, 2005).

\section{Migration and introduction of the pathogen}

Rusts are among the most devastating diseases of wheat in many regions in the world (Singh et al., 2004). Yellow (stripe) rust on wheat is present in most wheat growing regions (Chen, 2005).

The first records of yellow rust in the USA were in 1915, but there were no potentially serious outbreaks until 1960's which were reported in the western states (Line, 2002). Yellow rust first appeared in Eastern Australia in 1979, and then spread to New Zealand in 1980 (Wellings et al., 1987). Yellow rust was reported for the first time in South Africa in 1996 and 8 years after to Western Australia, the genotype of this new fungal isolate suggesting that it may be derived from East Africa (Boyd, 2005).

Rusts are widespread diseases across all major wheat growing regions with diverse cropping systems, growing seasons and germplasm traits (Singh et al., 2004). The three rust pathogens differ in their climatic adaptation. Stripe rust was reported to be prevalent in cooler and wetter regions, temperate and maritime regions, and high elevation. However, recent disease outbreaks, which have hit many countries closer to the equator, suggest a new level of adaptation.
Stripe rust is widely distributed across all continents except Antarctica (Fig. 5). Its epidemics have become more frequent in the USA (particularly the Pacific Northwest region of North America), South America, North Africa (Morocco, Algeria and Tunisia), East Africa (Ethiopia and Kenya), East Asia (Northwest and Southwest China), South Asia (India, Pakistan and Nepal), Australasia (Australia and New Zealand), the Nile Valley and Red Sea (Egypt and Yemen), West Asia (Lebanon, Syria, Turkey, Iran, Iraq and Afghanistan,), Central Asia (Kyrgyzstan, Uzbekistan, Tajikistan and Turkmenistan), Caucasus (Georgia, Armenia and Azerbaijan) and Europe (UK, Northern and Southern France, the Netherlands, Northern Germany, Denmark, Spain and Sweden) (Solh et al., 2012).

Transcaucasia was suggested by Hassebrauk (1965) and later by Stubbs (1985) as the center of origin for Pst. Recent studies of Pst populations reported highest levels of genetic diversity and recombinant population structure in Himalayan and near-Himalayan region. These findings supported the region as most likely the center of origin and diversity for $P$. striiformis (Ali et al., 2014; Thach et al., 2016).

\section{Pathogen dispersal}

Long distance dispersal (LDD) is an important mechanism facilitating the colonization of new habitat. It permits for many organisms to migrate between summer and winter habitats (Brown et al., 2002). The comparison of disconnected populations of yellow rust and dispersal data showed that Pst can undergo long distance dispersal (Ali et al., 2014).

World population's distribution of Pst showed evidence of international migration (Fig. 6). Pst populations studies confirmed the NW Europe as the putative source of North American (1900), South American (20th century) and Australian (1979) populations.

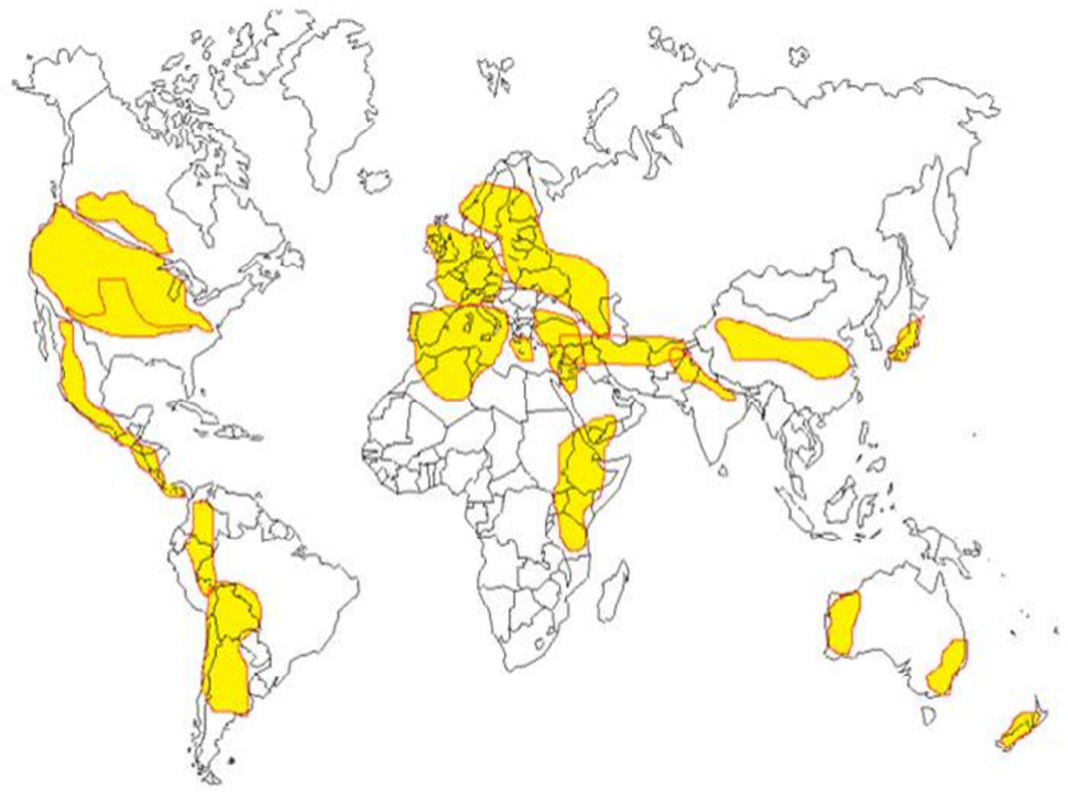

Fig. 5. Worldwide geographical distribution of stripe rust (Brar, 2015) 
416

ABC analyses of Pst worldwide populations showed that NW European population is the result of an admixture event between China and Pakistan population. Thus, it was suggested that Pst has spread from China to NW Europe through human interventions. The recently spreading of aggressive isolates is a real world example of stepwise regional dispersal of stripe rust pathogen (Ali et al., 2014).

Viability of spores is influenced by humidity. Spores need to withstand dry weather to survive and travel long distances. Besides, urediniospores are dispersed by rain and dissemination of spores by rain splash aids in quick dispersal of the pathogen. Above all, wind dispersal allows stripe rust pathogen to travel for long distances. The timing, type, and direction of winds determine the earliness, scale and development rate of stripe rust epidemics (Chen, 2005).

\section{Stripe rust losses}

Stripe rust of wheat is the most important rust pathogen of wheat worldwide and because the disease attacks from early in the growing season, plants are usually stunted and weakened, causing severe yield losses up to $70 \%$. The disease reduced yield, quality and size of the harvested grains. On susceptible varieties, disease development at the seedling stage can cause total yield loss (Chen, 2005). However, the severity of stripe rust depends on host resistance, time of initial infection, rate of disease development and disease duration. According to Doling and Doodson (1968) and Roelfs (1978), losses of up to $20 \%$ and $75 \%$ in wheat were reported in the USA. Based on greenhouse experiments, a potential yield loss up to $65 \%$ was recorded on a susceptible cultivar (Wellings, 2011).

A large epidemics of wheat stripe rust occurred in other regions in the world including North Africa and the Middle East in the 1970s (Saari et al., 1985). These epidemics occurred because of the presence of $Y r 2$ gene in most of the cultivars at that time (McIntosh et al., 2009). Losses of nearly 2.25 million US \$ were estimated in the 1998 in South Africa (Pretorius, 2004). In China, a widespread stripe rust epidemic affected about 6.6 million hectares of wheat in 11 provinces during the growing season 20012002, causing a yield loss of $13 \mathrm{M}$ tones (Wan et al., 2004). Substantial losses were reported between 1999 and 2000 in central Asia with a yield losses ranged from 20 to $40 \%$ (Morgounov et al., 2004). In Australia, fungicide costs was estimated to 40 million AU\$ in 2003 (Wellings et al., 2004). The most severe yield losses recorded in the USA were estimated in more than $9 \mathrm{M}$ bushels of wheat in 2000, when the disease appeared in at least 20 states (Markell et al., 2008).

\section{Stripe rust management \\ Using plant resistance}

Using resistant cultivars is the most efficient, economic, and environmentally safe approach to control rust diseases. To date, more than 187 rust resistance genes were described (Aktar-Uz-Zaman et al., 2017).

More than half a million wheat genetic resources and their wild relatives are conserved in gene banks all over the world. Discovering their favorable genetic diversity for breeding is crucial for enhancing grain yield potential needed to avert future food shortages (Longin et al., 2014). The genus Triticum comprises three ploidy levels (Fig. 7) and approximately 30 species (Feldman et al., 2012). Harlan and de Wet (1971) developed a concept of gene pool and decided it would be useful to divide the crop gene pool into different pools, which allowed phylogenetic separation of the germplasm based on introgression rates that can potentially occur between the cultivated crops and their ancestors (Harlan et al., 1971).

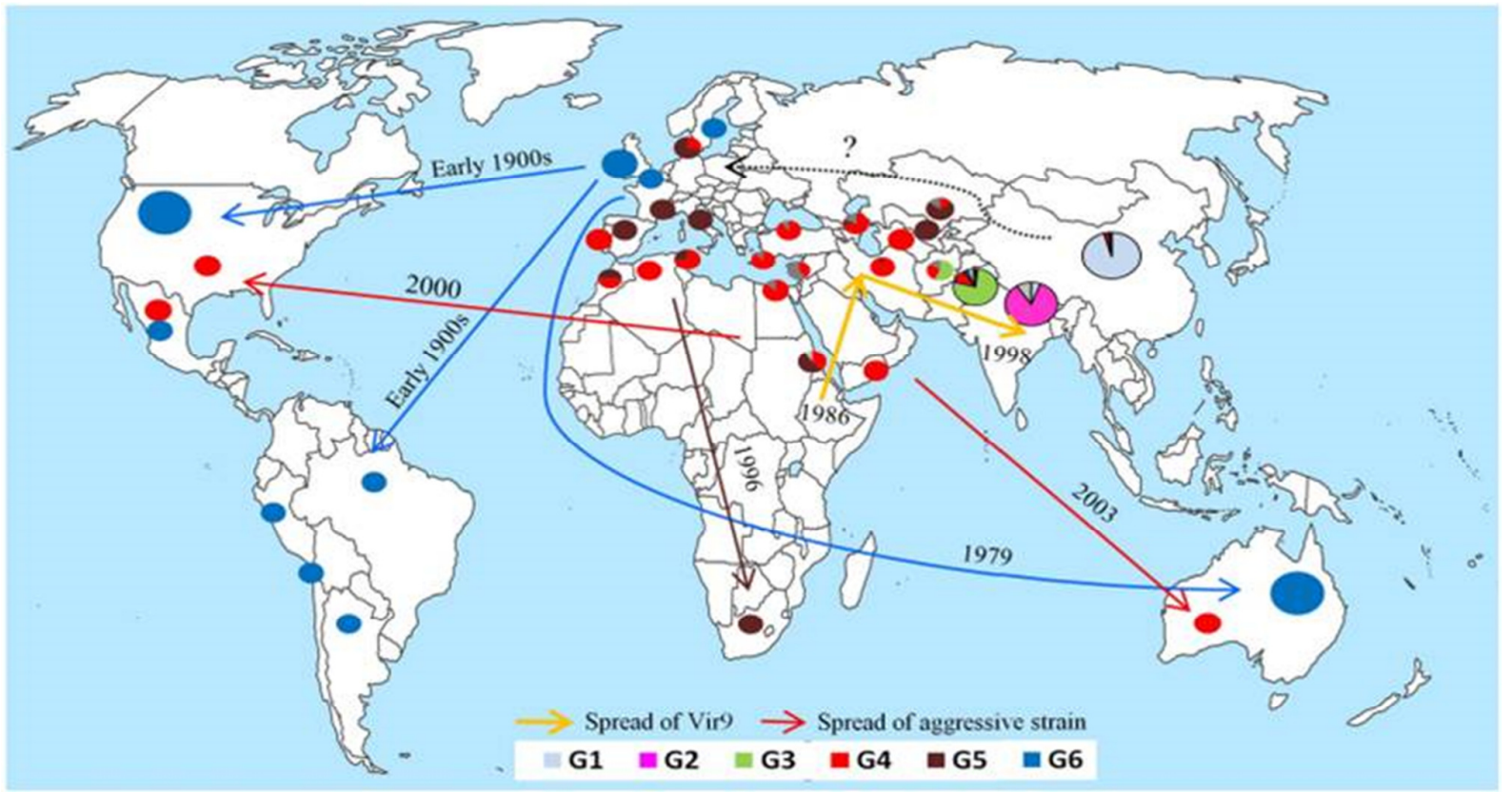

Fig. 6. Origin and migration routes of recently emerged populations of wheat yellow rust pathogen identified or confirmed through population genetic analyses of a worldwide representative set of isolates (Ali et al., 2014) 


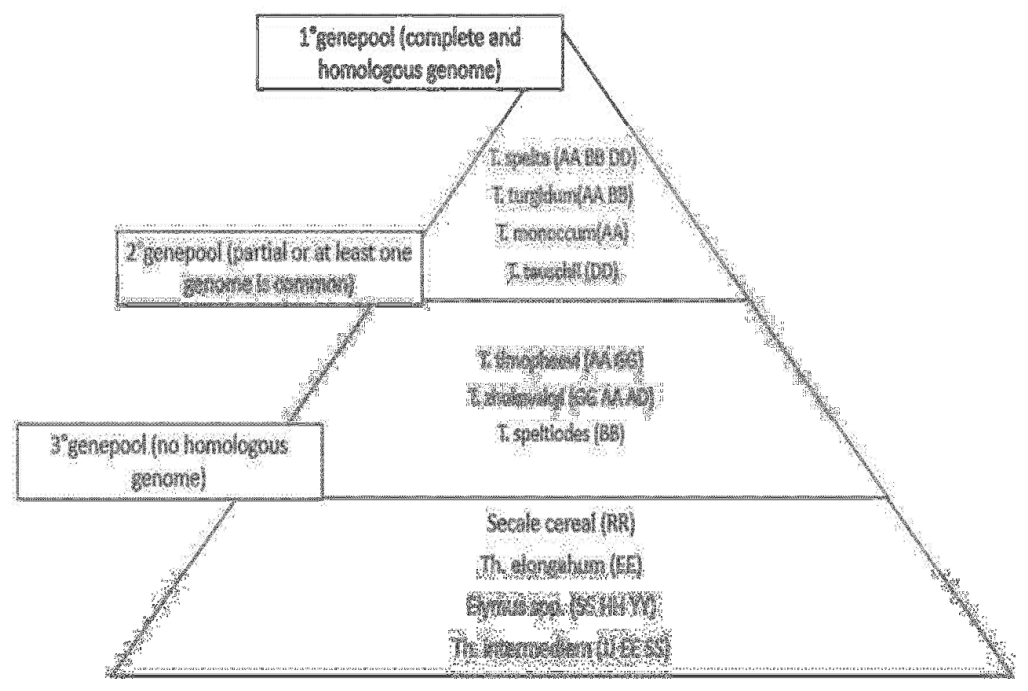

Fig. 7. Wheat gene pool representing various species (Pratap et al., 2014)

The primary gene pool consists of all biological species, including cultivated races, wild and weedy relative forms of a crop species. Gene transfer from the primary gene pool is easy and $\mathrm{F}_{1}$-hybrids are fertile with normal chromosome pairing. Biological species from the secondary gene pool hybridize with the primary gene pool with some difficulty. In the tertiary gene pool, gene transfer is very difficult and requires special methods. Secondary and tertiary gene pools represent a wide and yet little exploited reservoir of desirable alien genes that can be incorporated with some difficulty into cultivated wheat genotypes (Feuillet et al., 2009; Pratap et al., 2014).

Wild relatives of wheat may be a rich resource for new resistance genes for stripe rust. Thus widening the genetic base is a priority and primary target to improve the resistance of wheat varieties to cope with changing races of $P_{s t}$ is the preferred strategy for achieving global wheat demand (Cox, 1997).

\section{Plant disease resistance genes}

To date, 78 stripe rust resistance genes $(Y r 1-Y r 78)$ were officially been catalogued according to the 2017 Catalogue of Gene Symbols for Wheat (McIntosh et al., 2010). The symbol ' $Y r$ ' is used to designate specific resistance gene against stripe rust.

Stripe rust resistance genes were introduced into hexaploid wheat either by recombination with species within the primary wheat genepool, or by introgression of translocated chromosomes segments from secondary and tertiary gene pools. Many stripe rust resistance genes were linked to genes resistant to other fungal pathogens, such as Yr9 linked to $\operatorname{Lr} 26 / \mathrm{Sr} 31 / \mathrm{Pm} 8$, and $\mathrm{Yr} r 7$ linked to Lr37/Sr38 (Sharma, 2012). Most of the stripe rust resistance genes were derived from common wheat (Triticum aestivum), although some were derived from different wild species, such as Triticum spelta album, Triticum dicoccoides, Triticum spelta, Secale cereale, Aegilops comosa, Aegilops ventricosa, Triticum tauschii and Haynaldia villosa (Aktar-Uz-Zaman et al., 2017).
According to the Federation of British Plant Pathologists (1973), resistance in general, has been defined as "the ability of an organism to withstand or oppose the operation of, or to lessen or overcome the effects of an injurious or pathogenic factor".

A basic compatibility (pathogenicity factors) between a plant and pathogen is required for a pathogen to recognize and overcome the nonhost or basic resistance of the host. The capacity of a pathogen to cause disease is called virulence and the plant response is susceptible. The incapability to cause disease is named avirulence where the plant response is resistant (Surico, 2013).

The gene-for-gene concept: according to Flor (1964 and 1971) studies, the gene-for-gene concept is based on the observation that for each resistance gene $(\mathrm{R})$ in the host there is a corresponding a virulence gene (Avr) in the pathogen. The interaction between the two genes leads to hypersensitive reaction (HR) resulting to incompatibility (Higgins et al., 1998). Based on Flor's definition, Person (1959) defined this concept as follows "where a hostpathogen relationship exists when the presence of a gene in the host is contingent on the presence of a gene in the pathogen, and where the interaction between the two genes leads to a single phenotypic expression". Thus, the presence or absence of the relevant gene in either organism may be recognized (Hysing, 2007).

Race specific resistance is also referred to as a major gene resistance, gene for gene resistance, or seedling resistance. Race-specific resistance genes are recognized by the presence of low infection types (Rajaram et al., 2002). Resistance extends from seedling stage into adult stages. Race specific resistance is controlled by major genes (genes with major effects), and it often "breaks down" easily with the occurrence of new pathotypes of a pathogen (McDonald $e t$ al., 2002; Knott, 2008).

Race nonspecific resistance: this type of resistance is controlled by the interaction of a few or several genes having minor to intermediate effects. In race nonspecific reaction there is a reaction of one host genotype to different 
418

pathogen isolates. The genetic nature of this type of rust resistance is usually complex (Francisco et al., 2001). Vanderplank (1963) used the terms vertical resistance and horizontal resistance for 'specific' and 'non-specific' resistance, respectively (Al-Khayri et al., 2016).

Slow rusting: is a type of resistance, in which disease develops slowly, resultingin intermediate to low disease levels against all pathotypes of a pathogen. Effect of slow rusting gene is characterized by longer latent period, low susceptibility or infection frequency, smaller uredial size, reduced duration of sporulation and lower density of spore production, that can affect disease progress in the field (Ellis et al., 2014; Kumar et al., 2015).

Durable resistance: Johnson (1988) defined durable disease resistance as "resistance that has remained effective while a cultivar possessing it was widely cultivated in an environment favoring the disease". Durable resistance sometimes represents the adult plant resistance (APR), which is associated by combinations of several minor genes acting additively and shows non-hypersensitive reactions. However, some APR genes provide partial resistance that is effective against specific races of a given pathogen species i.e. race specific. The French bread wheat variety "Camp remy" was an example of varieties with resistance to stripe rust, grown and remained resistant to all pathotypes of Pst for more than 20 years (Mallard et al., 2005).

\section{Type of resistance to strip rust}

In general, resistance to stripe rust is categorized as seedling resistance (Table 1 ), which can be expressed in all stages, also referred as to as all stage resistance and adult plant resistance, which express in adult stages (Chen, 2005; Bulli et al., 2016). Seedling resistance and some types of adult plant resistance are race specific resistance and they come with risk of emergence of new more virulent races due to high selection pressure on the pathogen (Chen, 2005; Jin et al., 2010; Wellings, 2011).

High temperature adult plant resistance (HTAP) (Table 1) is a nonspecific type of resistance, which becomes increasingly effective with high temperatures and when plants grow old. HTAP has proven to be more durable than seedling resistance. However, HTAP resistance is susceptible to all races of Pst at early stages of wheat development (Chen, 2005, 2013). The combination of non-race specific HTAP and race-specific all-stage resistances is suggested to be the most effective approach for controlling the disease because all-stage resistance can provide high levels of resistance, until new virulent races circumvent and HTAP resistance can reduce damage when the all-stage resistance is overcome by new races (Chen, 2005).

The molecular markers and marker assisted selection has produced very favourable results in facilitating mapping genes to stripe rust and. In contrast, gene-pyramiding using conventional methods is difficult, time-consuming and requires concurrent tests of the same wheat breeding materials with several different rust races before making a selection (Aktar-Uz-Zaman et al., 2017).

More recently developed types of molecular markers, such as random amplified polymorphic DNA (RAPD), simple sequence repeat (SSR) markers and amplified fragment length polymorphism (AFLP), are used to characterize and compare rust populations (Chen, 2005). Molecular markers are available for $\operatorname{Yr} 5, \operatorname{Yr} 9, \operatorname{Yr} 10, \operatorname{Yr} 15$, Yr18, Yr24, Yr26, Yr28, Yr32, Yr33, Yr34, Yr36, YrH52 and Yrns-B1. The clone of a gene like sequence for resistance to disease was developed for $\operatorname{Yr} 17$; it is a similar to the resistance gene analog polymorphism (PGAP) (Chen, 2005).

\section{Using fungicides}

Fungicide application is a necessary approach to fight against stripe rust disease (Line, 2002; Chen, 2005; Wan et al., 2007). Various synthetic substances were applied to control this disease. Commercial fungicide products were used worldwide. They include Tilt, Evito, Quadri, Prosaro, Stratego and Quilt (Chen, 2007). Currently, the following active ingredients are labelled for control of stripe rust in Morocco: propiconazole, azoxystrobin, propiconazole in combination with trifloxystrobin, strobilurin and azoxystrobinin combination with propiconazole. These labelled fungicides with different active ingredients provide choices for growers to use and may reduce selection pressure in the fungal pathogen to develop resistance to chemicals.

The importance of using fungicides was demonstrated in field experiments near Pullman Washington during successive growing seasons from 2002 to 2012. They were conducted to improve chemical control of stripe rust for major commercially grown cultivar with various levels of resistance. The findings of this study showed that fungicide application reduced AUDPC (Area under Disease Progress Curve) by more than $80 \%$ in both susceptible winter wheat and susceptible spring wheat when compared to untreated controls. The AUDPC reduction depends on the duration and severity of disease. Tilt (Propiconazole) was used throughout this study and became the standard fungicide to control stripe rust during this period (Chen, 2014). Triadimenfon (Bayleton) was largely used to control wheat stripe rust in China (Wan et al., 2007). The timing of spraying fungicides is crucial for an effective control of stripe rust (Chen, 2005, 2007). Viljanen-Rollinson et al. (2006) revealed that using fungicides early in the growing season leads to a better disease control.

However, the use of fungicides adds high input costs to wheat production, which is a burden for many growers, especially in developing countries. It causes numerous negative health and environmental issues. Furthermore, repeated applications may result in the selection of fungicide resistant strains of the pathogen (Chen, 2005).

\section{Cultural methods}

Cultural methods provide another strategy to partially control wheat stripe rust. Using a series of cultural practices significantly enhances the existing sources of resistance. As a result, crop management in terms of a combination of crop choice, timing of seeding and removing volunteer cereals may provide effective control of stripe rust (Roelfs, 1992; Wan et al., 2007).

Stripe rust requires green material to survive from one season to next, it is known as "green bridge". Removing volunteer plants (the Green Bridge) that will support stripe rust survival is an effective control measure for epidemics that result from endogenous inoculum (Roelfs, 1992). Planting a mixture of wheat varieties with different 
Table 1.Types of resistance to stripe rust based on various ways of separation with modifications (Chen, 2013)

\begin{tabular}{|c|c|c|c|}
\hline Ways for separation & Types of resistance & Definition & Durability \\
\hline \multirow[t]{2}{*}{ Growth stage } & All-stage (seedling) resistance & $\begin{array}{l}\text { Resistance can be detected in the } \\
\text { seedling stage but remains effective } \\
\text { throughout all growth stages. }\end{array}$ & Usually not durable \\
\hline & Adult plant resistance & $\begin{array}{l}\text { Plants with adult plant resistance are } \\
\text { susceptible in the seedling stage but } \\
\text { become resistant in late stage. }\end{array}$ & Usually durable \\
\hline \multirow[t]{2}{*}{ Degree of resistance } & Complete resistance (immune) & $\begin{array}{l}\text { Resistant plants do not show any } \\
\text { visible disease symptom or pathogen } \\
\text { sign. }\end{array}$ & Usually not durable \\
\hline & Incomplete (partial) resistance & $\begin{array}{l}\text { Resistance is not complete, showing } \\
\text { various degree of reduction in } \\
\text { infection type and/or severity. }\end{array}$ & Usually durable \\
\hline \multirow[t]{2}{*}{ Sensitivity to pathogen infection } & Hypersensitive resistance & $\begin{array}{l}\text { Resistant plants show necrotic tissue } \\
\text { result from cell death. }\end{array}$ & Often not durable \\
\hline & Non hypersensitive response & $\begin{array}{l}\text { Either completely resistant (immune) } \\
\text { or reduced severity, but susceptible } \\
\text { infection type (e.g. slow rusting). }\end{array}$ & Depends \\
\hline \multirow[t]{2}{*}{ Number of genes } & Monogenic resistance & $\begin{array}{c}\text { Resistance is controlled by a single } \\
\text { gene. }\end{array}$ & Usually not durable \\
\hline & Polygenic resistance & $\begin{array}{l}\text { Resistance is controlled by several to } \\
\text { many genes. }\end{array}$ & Usually durable \\
\hline \multirow[t]{2}{*}{ Inheritance } & Qualitative resistance & $\begin{array}{l}\text { Resistance is inherited qualitatively, } \\
\text { showing distinct two classes in a } \\
\text { segregating population from a cross } \\
\text { with a susceptible genotype. }\end{array}$ & Usually not durable \\
\hline & Quantitative resistance & $\begin{array}{l}\text { Resistance is inherited quantitatively, } \\
\text { showing continuous variation in a } \\
\text { segregating population. }\end{array}$ & Usually durable \\
\hline \multirow[t]{2}{*}{ Specificity } & Race specific resistance & $\begin{array}{l}\text { Resistance is effective against some } \\
\text { races, but not effective against other } \\
\text { races. }\end{array}$ & Usually not durable \\
\hline & Non race specific resistance & Resistance is effective against all races & Usually durable \\
\hline
\end{tabular}

resistance backgrounds may significantly reduce disease pressure and may also increase or stabilize wheat yield (Wolfe, 1985). Mechanisms by which cultivar mixtures suppress disease may include dilution of spore's density because of the greater distance between susceptible plants, a physical barrier created by the resistant plants in the canopy that interrupt spore movement and induced resistance (Castro, 2001; Huang et al., 2012) are also convenient.

\section{Challenge of stripe rust control}

\section{Climate change}

Increased temperatures could affect the phenological growth stages of wheat (Juroszek et al., 2013). For example, temperatures more than $34^{\circ} \mathrm{C}$ could reduce the grain filling period of wheat and accelerate plant senescence (Asseng $e t$ al., 2011). Increased leaf senescence indirectly affects pathogens development especially biotrophic fungi such as
Puccinia species. High temperatures also directly impede diseases development (Juroszek et al., 2013). Results showed that pathogens may adapt themselves to warmer temperatures (Chakraborty et al., 2011).

Climate change, in terms of rising temperatures, and the timing and increasing variability of rainfall, influences the spread and severity of rust diseases. In wheat, the expression of many genes for resistance to stripe rust is influenced by temperature and/or plant developmental stage. Findings of a weakening of stripe rust resistance and pathogen adaptation due to temperature increases were well documented in annual race surveys in the Eastern USA (Markell et al., 2008). In contrast, some stripe rust resistance genes, such as $\mathrm{Yr} 18$, are known to be temperature mediated and become more effective at higher temperatures (AktarUz-Zaman et al., 2017). Therefore, in varieties with this resistance gene, there may be an enhancement of the 
420

effectiveness of resistance in a warming climate. On the other hand, Kaur et al. (2008) have predicted that the importance of wheat stripe rust disease might be reduced in the future in Punjab state of India due to climate change.

New pathotypes of Pst can adapt to increased temperatures. In the Eastern USA Pst races, collected after 2000, have different virulence profiles than races collected before this year. These new races pose an increased risk to wheat crops as the results of latent period and spore germination indicated that the new population was better adapted to high temperature (Chen, 2005).

\section{High epidemic potential}

Many yellow rust epidemics (Sanders, 2018) were reported in Central and West Asia and East and North Africa. The 2009-2010 epidemic severely affected many countries including Morocco, Turkey, Algeria, Syria, Lebanon, Iraq and Uzbekistan. Syria and Lebanon were the worst hit of this epidemic; Syria lost nearly half of its wheat harvest. In 2014, the Central Research Institute for Field Crops in Ankara and the Regional Cereal Rust Research Center in Izmir confirmed the detection of a new Pst race in Turkey. The newly detected strain was "Warrior" race previously identified in the United Kingdom in 2011. Some of Turkish commercial cultivars known to be resistant to the previously characterized races of Pst were recorded as fully susceptible to this new race. The warrior race was much more widespread in the following year after its first detection. It was already present in high frequencies in most European countries and North Africa (Mert et al., 2016) and it was confirmed in Morocco in 2013 and in Algeria in 2014 (Rust Tracker, 2011). This race was very dissimilar to pre-2011 European races. It showed relatively higher genetic diversity than other previous races(Hovmøller et al., 2016).

\section{Conclusions}

Wheat stripe rust continues to be a major worldwide limiting factor of wheat production. Global losses were estimated to be at 5.5 million tons per year. The evolution of pathogen races becomes larger and faster; the emergence of new races with high epidemic potentials and which can adapt to warmer temperatures has expanded virulence profiles. The new highly aggressive strains have defeated key resistance genes such as $Y r 27$, used in breeding of many wheat cultivars across Asia and Africa, which led to the epidemic in 2009-2010. Climate change is aggravating the severity and frequency of today's new wheat problems. Warmer winters induce earlier stripe rust infection and spread. Thus, the severity of the epidemics will increase throughout all wheat growing regions. Growing resistant cultivars is the major component of integrated control of stripe rust. However, the "breakdown" of resistance following the introduction of new genes for resistance is a major problem. Successful deployment of resistant crop varieties at larger scales and in different regions would, however, require: a better understanding of pathogen diversity; regional and international collaboration to effectively address the disease through data sharing; a long term effort to control new and existing challenges to stripe rust through research and development of resistant varieties to emerging strains.

\section{Acknowledgements}

The authors are grateful to the Phytopathology Unit, Department of Plant Protection and Environment, Ecole Nationale d'Agriculture de Meknès, for the financial support of this work.

\section{References}

Acevedo E, Silva P, Silva H (2006). Growth and wheat physiology, development. Laboratory of Soil-Plant-Water Relations. Faculty of Agronomy and Forestry Sciences. University of Chile. Casilla, 1004.

Aktar-Uz-Zaman M, Tuhina-Khatun M, Hanafi MM, Sahebi M (2017). Genetic analysis of rust resistance genes in global wheat cultivars: an overview. Biotechnology \& Biotechnological Equipment 31(3):431445.

Al-Khayri JM, Jain SM, Johnson DV (2016). Advances in plant breeding strategies: Agronomic, Abiotic and Biotic Stress Traits, Springer.

Ali S, Gladieux P, Leconte M, Gautier A, Justesen AF, Hovmøller MS, Enjalbert J, De Vallavieille-Pope C (2014). Origin, migration routes and worldwide population genetic structure of the wheat yellow rust pathogen Puccinia striiformis f. sp. tritici. PLoS Pathogens 10(1): e1003903.

Ali S, Rodriguez-Algaba J, Thach T, Sørensen CK, Hansen JG, Lassen P,Nazari K, Hodson DP, Justesen AF, Hovmøller MS (2017). Yellow rust epidemics worldwide were caused by pathogen races from divergent genetic lineages. Frontiers in Plant Science 8:1057.

AssengS, Foster I, Turner NC (2011). The impact of temperature variability on wheat yields. Global Change Biology 17(2):997-1012.

Baily J (2013). Molecular and host specificity studies in Puccinia striiformis in Australia. Doctor of Philosophy, PhD Thesis, The University of Sydney, Plant Breeding Institute, Narrabi.

Balaghi R, Jlibene M, Tychon B, Eerens H (2012). La prédiction agrométéorologique des rendements céréaliers au Maroc [Agrometeorological prediction of cereal yields in Morocco]. INRA, Maroc.

Berlin A, Samils B, Andersson B (2017). Multiple genotypes within aecial clusters in Puccinia graminis and Puccinia coronata: improved understanding of the biology of cereal rust fungi. Fungal Biology and Biotechnology 4(1):3.

Boshoff W, Pretorius Z, van Niekerk B (2003). Fungicide efficacy and the impact of stripe rust on spring and winter wheat in South Africa. South African Journal of Plant and Soil 20:11-17.

Boyd L (2005). Can Robigus defeat an old enemy?-Yellow rust of wheat. The Journal of Agricultural Science 143(4):233-243.

Brar GS (2015). Population structure of Puccinia striiformis f. sp. tritici, the cause of wheat stripe rust, in western Canada. Master of Science., University of Saskatchewan, Saskatoon.

Brown JK, Hovmøller MS (2002). Aerial dispersal of pathogens on the global and continental scales and its impact on plant disease. Science 297(5581):537-541.

Bulli P, Zhang J, Chao S, Chen X, Pumphrey M (2016). Genetic architecture of resistance to stripe rust in a global winter wheat germplasm collection. G3 (Bethesda) 6(8):2237-2253.

Cartwright D, Russell G (1981). Development of Puccinia striiformis in a 
susceptible winter wheat variety. Transactions of the British Mycological Society 76(2):197-204.

Castro A (2001). Cultivar mixtures. The Plant Health Instructor.

Chakraborty S, Newton AC (2011). Climate change, plant diseases and food security: an overview. Plant Pathology60(1):2-14.

Chen X (2005). Epidemiology and control of stripe rust [Puccinia striiformis f. sp. tritici] on wheat. Canadian Journal of Plant Pathology 27(3):314 337.

Chen X (2007). Challenges and solutions for stripe rust control in the United States. Australian Journal of Agricultural Research 58(6):648655.

Chen X (2013). High-temperature adult-plant resistance, key for sustainable control of stripe rust. American Journal of Plant Sciences 4(03):608.

Chen X (2014). Integration of cultivar resistance and fungicide application for control of wheat stripe rust. Canadian Journal of Plant Pathology 36(3):311-326.

Confalonieri R, Francone C, Cappelli G, Stella T, Frasso N, Carpani M, M, Bregagiio S, Acutis M, Tubiello F, Fernandes E (2013). A multiapproach software library for estimating crop suitability to environment. Computers and Electronics in Agriculture 90:170-175.

Conner R, Kuzyk A (1988). Effectiveness of fungicides in controlling stripe rust, leaf rust and black point in soft white spring wheat. Canadian Journal of Plant Pathology 10:321-326.

Cox T (1997). Deepening the wheat gene pool. Journal of Crop Production $1(1): 1-25$.

Curtis B (2002). Wheat in the world. Bread wheat: Improvement and production. No. CIS-3616. CIMMYT.

Curtis B, Rajaram S, Macpherson H (2002). FAO Plant Production and Protection Series, No. 30. Bread Wheat: Improvement and Production. No.CIS-3616. CIMMYT

Dixon J, Braun H, Crouch J (2009). Overview: transitioning wheat research to serve the future needs of the developing world. Wheat Facts and Futures 1-25.

ElMekki AA(2006). Cereals policies in Morocco.

Ellis JG, Lagudah ES, Spielmeyer W, Dodds PN (2014). The past, present and future of breeding rust resistant wheat. Frontiers in Plant Science 5:641.

FAO (2017). Food and Agriculture Organization of united nations. Retrieved 2018 March 31 from http:// www. fao.org/ giews/ countrybrief/country.jpp?code $=$ MAR

FAO (2018). Food and Agriculture Organization. Retrieved 2018 March 31 from http://www.fao.org/worldfoodsituation/csdb/en/

FAOSTAT (2018). Agriculture Organization of the United Nations. Statistical Database. Retrieved 28 February 2018 from. http://faostat.fao.org

Feldman M, Levy AA (2012). Genome evolution due to allopolyploidization in wheat. Genetics 192(3):763-774.

Feuillet C, Muehlbauer GJ (2009). Genetics and genomics of the Triticeae (Vol.7).Springer Science \& Business Media.

Francisco XRdV, Parlevliet JE, Zambolim L (2001). Concepts in plant disease resistance. Fitopatologia Brasileira 26:577-589.

Getie B (2015). Identification, genetic studies and molecular characterisation of resistance to rust pathogens in wheat. Doctor in philosophy, the university ofSydney, Plant Breeding Institute, Cobbitty, March 2015.

Gommes R, El Hairech T, Rosillon D, Balaghi R, Kanamaru H (2009). Impact of climate change on agricultural yields in Morocco. Rome: FAO. Retrieved 201422 April from ftp: //extftp.fao.org/SD/Reserved /Agromet/

WB_FAO_morocco_CC_yield_impact/report/GoncharovNP,

Golovnina KA, Kondratenko EY (2009). Taxonomy and molecular phylogeny of natural and artificial wheat species. Breeding Science 59(5):492-498.

Harlan JR, de Wet JM (1971). Toward a rational classification of cultivated plants. Taxon 509-517.

Higgins VJ, Lu H, Xing T, Gelli A, Blumwald E (1998). The gene-for-gene concept and beyond: Interactions and signals. Canadian Journal of Plant Pathology 20(2):150-157.

Hovmoller MS, Sorensen CK, Walter S, Justesen AF (2011). Diversity of Puccinia striiformis on cereals and grasses. Annual Review of Phytopathology 49:197-217.

Hovmøller MS, Walter S, Bayles RA, Hubbard A, Flath K, Sommerfeldt N, Thach T (2016). Replacement of the European wheat yellow rust population by new races from the centre of diversity in the near-Himalayan region. Plant Pathology 65(3):402-411.

Huang C, Sun Z, Wang H, Luo Y, Ma Z (2012). Effects of wheat cultivar mixtures on stripe rust: A meta-analysis on field trials. Crop Protection 33:52-58.

Hysing S-C (2007). Genetic resources for disease resistance breeding in wheat. $\mathrm{PhD}$ thesis, Swedish University of Agricultural Sciences, Alnarp,

Jin Y, Szabo LJ, Carson M (2010). Century-old mystery of Puccinia striiformis life history solved with the identification of Berberis as an alternate host. Phytopathology 100(5):432-435.

Juroszek P, von Tiedemann A (2013). Climate change and potential future risks through wheat diseases: a review. European Journal of Plant Pathology 136(1):21-33.

Kaur S, Dhaliwal L, Kaur P (2008). Impact of climate change on wheat disease scenario in Punjab.Journal of Research 45(3-4):161-170.

Knott D (2008). The genomics of stem rust resistance in wheat. Plant Sciences Department, University of Saskatchewan, Saskatoon, Saskatchewan, S7N5A8, Canada.

Kumar S, Kumari J, Bansal R, Kuri B, Singh AK, Wankhede D, Akhtar J,Khan Z (2015). Slow rusting-an effective way to achieve durable resistance against leaf rust in wheat. Wheat Information Service 120:26.

Leff B, Ramankutty N, Foley JA (2004). Geographic distribution of major crops across the world. Global Biogeochemical Cycles 18(1).

Line RF (2002). Stripe rust of wheat and barley in North America: a retrospective historical review. Annual Review in Phytopathology 40:75-118

Liu B, Chen X, Kang Z (2012). Gene sequences reveal heterokaryotic variations and evolutionary mechanisms in Puccinia striiformis, the stripe rust pathogen. Open Journal of Genomics 1(1).

Longin CFH, ReifJC (2014). Redesigning the exploitation of wheat genetic resources. Trends in Plant Science 19(10):631-636.

$\mathrm{MaQ}$, Shang H (2009). Ultrastructure of stripe rust (Puccinia striiformis f.sp. tritici) interacting with slow-rusting, highly resistant, and susceptible 
422 wheat cultivars. Journal of Plant Pathology 1:597-606.

MallardS, Gaudet D, Aldeia A, Abelard C, Besnard A, Sourdille P, Dedryver $F$ (2005). Genetic analysis of durable resistance to yellow rust in bread wheat. Theoretical and Applied Genetics 110(8):1401-1409.

Markell S, Milus E (2008). Emergence of a novel population of Puccinia striiformis f. sp. tritici in eastern United States. Phytopathology 98(6):632-639.

McDonald BA, Linde C (2002). Pathogen population genetics, evolutionary potential, and durable resistance. Annual Review of Phytopathology 40(1):349-379.

McIntoshA R (2009). History and status of the wheat rusts. Paper presented at the Proceedings of the 2009 Technical Workshop Borlaug Global Rust Initiative, Cd. Obregon, Sonora, Mexico, March.

McIntosh R, Dubcovsky J, Rogers JW, Morris C, Appels R, Xia X (2010). Catalogue of gene symbols for wheat: 2011 Supplement. Annual Wheat Newsletter 57.

Mert Z, Nazari K, Karagöz E, Akan K, Öztürk İ, Tülek A (2016). First incursion of the warrior race of wheat stripe rust (Puccinia striiformisf.sp. tritici) to Turkey in 2014. Plant Diseases 100(2):528.

Moldenhauer J, Moerschbacher B, Van der Westhuizen A (2006). Histological investigation of stripe rust (Puccinia striiformis f. sp. tritici) development in resistant and susceptible wheat cultivars. Plant Pathology 55(4):469-474.

Morgounov A, Yessimbekova M, Rsaliev S, Baboev S, Mumindjanov H, Djunusova M (2004). High-yielding winter wheat varieties resistant to yellow and leaf rust in Central Asia Paper presented at the Proceedings of the 11th International Cereal Rusts and Powdery Mildews Conference.

Mrabet R (2000). Differential response of wheat to tillage management systems in a semiarid area of Morocco. Field Crops Research 66(2):165174.

Peng JH, Sun DNevo E (2011). Domestication evolution, genetics and genomics in wheat. Molecular Breeding28(3):281.

Pratap A, Kumar J (2014). Alien gene transfer in crop plants, Volume 2: Achievements and Impacts (Vol. 2), Springer Science \& Business Media.

Pretorius Z (2004). The impact of wheat stripe rust in South Africa. Paper presented at the Proceedings of the 11th International Cereal Rusts and Powdery Mildews Conference.

Rajaram S, Borlaug N, Van Ginkel M (2002). CIMMYT international wheat breeding. Bread wheat improvement and production. FAO, Rome 103-117.

Roelfs AP (1992). Rust diseases of wheat: concepts and methods of disease management. Cimmyt.

RustTracker (2011). RustTracker.org. Retrieved 2018 April 15 from. http://rusttracker.cimmyt.org/?page_id=9

SaariEE, Prescott J (1985). World distribution in relation to economic losses. In:Diseases, Distribution, Epidemiology, and Control pp 259-298.

Sanders R(2018). Strategies to reduce the emerging wheat stripe rust disease.

Schwessinger B (2017). Fundamental wheat stripe rust research in the 21st century. New Phytologist 213(4):1625-1631.

SharmaI (2012). Disease resistance in wheat. India, Cabi.

Sharma R, Nazari K, Amanov A, Ziyaev Z, Jalilov A (2016). Reduction of winter wheat yield losses caused by stripe rust through fungicide management. Journal of Phytopathology 164:671-677.

Shiferaw B, Prasanna BM, Hellin JBänziger M (2011). Crops that feed the world 6. Past successes and future challenges to the role played by maize in global food security. Food Security 3(3):307.

Siad SM, Gioia A, Hoogenboom G, Iacobellis V, Novelli A, Tarantino E, Zdruli P (2017). Durum wheat cover analysis in the scope of policy and market price changes: A case study in Southern Italy. Agriculture $7(2): 12$.

Singh R, Mahmoudpour A, Rajkumar M, Narayana R(2017). A review on stripe rust of wheat, its spread, identification and management at field level. Research on Crops 18(3):528-533.

Singh RP, William HM, Huerta-Espino JRosewarne G (2004). Wheat rust in Asia: meeting the challenges with old and new technologies. Paper presented at the proceedings of the 4 th International Crop Science Congress, Brisbane, Australia.

Solh M, Nazari K, Tadesse W, Wellings C (2012). The growing threat of stripe rust worldwide. Paper presented at the Proceedings, Borlaug Global Rust Initiative, 2012 Technical Workshop, September 14, Beijing, China, Oral presentations.

Sørensen CK (2012). Infection biology and aggressiveness of Puccinia striiformis on resistant and susceptible wheat. PhD Thesis University of Aarhus,, Denmark, Nordre Ringgade, Aarhus.

Surico G (2013). The concepts of plant pathogenicity, virulence/avirulence and effector proteins by a teacher of plant pathology. Phytopathologia Mediterranea399-417.

Thach T, Ali S, de Vallavieille-Pope C, Justesen AF, Hovmøller MS (2016). Worldwide population structure of the wheat rust fungus Puccinia striiformis in the past. Fungal Genetics and Biology 87:1-8.

USDA (2014). United States Department of Agriculture. Retrieved 2018 March 23 from https: //www. fas. usda. Gov /data/worldagriculturalproduction.

USDA (2017). United States Department of Agriculture. Retrieved 2018 March 31 from https: //gain. fas.usda gov/ Recent $\%$ 20GAIN20Publications/Grain\%20and\%20Feed\%20Annual_Rabat_ Morocco_414-2017.pdf

Van der Plank J (1969). Pathogenic races, host resistance, and an analysis of pathogenicity. Netherlands Journal of Plant Pathology75(1-2):45-52.

Viljanen-Rollinson S, Marroni M, Butler R (2006). Wheat stripe rust control using fungicides in New Zealand. New Zealand Plant Protection 59:155-159.

Wan A, Chen X, He Z (2007). Wheat stripe rust in China. Australian Journal of Agricultural Research 58(6):605-619.

Wan A, Wang X, Kang Z, Chen X (2017). Variability of the stripe rust pathogen. In:Stripe Rust,Springer pp 35-154.

Wan A, Zhao Z, Chen X, HeZ, Jin S, Jia Q, Li G (2004). Wheat stripe rust epidemic and virulence of Puccinia strïformis f. sp. tritici in China in 2002. Plant Disease 88(8):896-904.

Wang MN, Chen X (2013). First report of Oregon grape (Mahonia aquifolium) as an alternate host for the wheat stripe rust pathogen (Puccinia strifformis f. sp. tritici) under artificial inoculation. Plant Disease 97(6):839-839.

Waqar A, Khattak SH, Begum S, Rehman T, Shehzad A, Ajmal W, Ali 
GM (2018). Stripe rust: A review of the disease, Yr genes and its molecular markers. Sarhad Journal of Agriculture 34(1).

Webb CA, Fellers JP (2006). Cereal rust fungi genomics and the pursuit of virulence and avirulence factors. FEMS Microbiology Letters 264(1):17.

Wellings C (2011). Global status of stripe rust: a review of historical and current threats. Euphytica 179(1):129-141.

Wellings C, Kandel K (2004). Pathogen dynamics associated with historic stripe (yellow) rust epidemics in Australia in 2002 and 2003. Paper presented at the Proceedings of the 11th international cereal rusts and powdery mildews conference.

Wellings C, McIntosh R, Walker J (1987). Puccinia striiformis f. sp. tritici in Eastern Australia possible means of entry and implications for plant quarantine. Plant Pathology 36(3):239-241.
Wolfe M (1985). The current status and prospects of multiline cultivars and variety mixtures for disease resistance. Annual Review of Phytopathology 23(1):251-273.

Yadav MK, Aravindan S, Ngangkham U, Shubudhi H, Bag MK, Adak T, Munda S, Samantaray S, Jena M (2017). Use of molecular markers in identification and characterization of resistance to rice blast in India. PloS One 12(4): e0176236.

Zheng W, Huang L, Huang J, Wang X, Chen X, Zhao J, Kang Z (2013). High genome heterozygosity and endemic genetic recombination in the wheat stripe rust fungus. Nature Communications 4:2673. 